\title{
Research on Compensation and Settlement for Land-lost Residents of "Village inside City" and Survival Condition--Take transformation of Shenghua Village, Jiang'an Development Zone, Wuhan City as an example
}

\author{
Yanling Xu, Mingfu Xie
}

Business College, University of Science and Technology of Wuchang, Wuhan, 430223, China

Keywords: land-lost residents; settlement and compensation; material life; spiritual life

\begin{abstract}
Through questionnaire survey, this paper mainly carried out survey and analysis on selection of compensation and settlement way, change of living condition, degree of income satisfaction, community culture construction, living habit, sense of security, and sense of belonging for transformation of Shenghua Village, Jiang'an Development Zone, Wuhan City, and makes a conclusion: although the material living level of villagers of Shenghua Village is improved, the employment conflict is highlighted with the change of their identities, and their spiritual life can't reach the expected effect. In urbanized reform and construction, it shall be noticed that the coordinated development and improvement of material life and spiritual life is an important condition for social progress. There exist some prominent problems in the transformation of "village inside city" in Wuhan City, such as exploitation and utilization of land, compensation and employment for land-lost peasants, and this paper will make a study on compensation and settlement for land-lost residents of Shenghua Village and their survival condition. Shenghua Village is located in Jiang'an District, Wuhan City; because it is located in downtown area, it is the key point in transformation of "village inside city" in Wuhan City. The transformation and demolition of this village were made in 2 phases. In phase 1, the vertical demolition was made along Erqi Road in north-south direction. As for demolition of old peach orchard area, the government demolished the $2^{\text {nd }}$ row of houses in the rear of the $1^{\text {st }}$ row of façade rooms. Phase 2 was demolition of old peach orchard, and the demolition was completed in the end of 2010. This paper obtains relevant data via questionnaire survey. There are totally 487 residents in Shenghua Village. We set problems as for obtaining the information of settlement and compensation, selection of compensation and settlement way, change of living condition, degree of income satisfaction, and cultural needs; we totally have issued 300 questionnaire and recovered 292 effective questionnaire.
\end{abstract}

\section{Current situation of compensation and settlement for land-lost residents of Shenghua Village}

According to the spirit of documents such as Opinions of CPC Wuhan Municipal Party Committee on Actively Promoting Comprehensive Transformation of "Village inside City" (W. F. [2004] No.13) and Reply of Municipal Bureau for Urban Planning on Planning of Comprehensive Transformation for Shenghua Village, Jiang'an District (W. G. H. [2009] No.385), Wuhan City implemented demolition for houses within Shenghua Village.

Table 1. Selection structure of settlement and compensation way of Shenghua Village

\begin{tabular}{|l|l|l|}
\hline Way of compensation & Number of households & Percentage (\%) \\
\hline Monetary indemnity & 15 & 3.08 \\
\hline $\begin{array}{l}\text { Equity swap compensation } \\
\begin{array}{l}\text { Monetary indemnity and equity } \\
\text { swap compensation }\end{array}\end{array}$ & 0 & 0 \\
\hline Total & 487 & 96.92 \\
\hline
\end{tabular}

Data source: Shenghua Industry Co., Ltd. (Shenghua Village Neighborhood Committee)

Most of villagers of Shenghua Village selected the combination of monetary indemnity and equity swap compensation, and they commonly thought that this way could most conform to the 
demand of realistic life and it was also most beneficial to demolished households. The secondary selection was monetary indemnity; they worried that the government and Shenghua Village Neighborhood Committee couldn't effectively execute compensation and settlement scheme. There was no person selecting single equity swap, for this way was not practical.

\section{Empirical analysis on compensation effect of land-lost residents of Shenghua Village}

\subsection{Empirical effect indicators}

2.1.1 Material living condition indicators

(1) Housing area

Currently, with rapid development of urban economic construction, the house that a family lives reflects the living condition of this family. Generally speaking, the larger the per capita living space is, the higher guarantee there is for material life.

(2) Income level

The income level is the basic guarantee for people's material life. The pursuit for happiness is human beings' eternal theme, and the sense of material happiness is most people's opinion. The general rule is that people with more income can enjoy more material wealth and feel happier. Therefore, the income level is the guarantee for people's material life, and it can reflect residents' living condition.

(3) Employment post

Different employment post provides different income level, and then forms different living condition. The employment post is also an important index which reflect the material condition of villagers of Shenghua Village. The employment post with high level reflects good material living condition, and vice versa.

(4) Welfare and guarantee

The social welfare and guarantee play an important role in people's living condition. The perfect welfare and social guarantee can guarantee people's material and spiritual life.

\subsubsection{Spiritual living condition indicators}

(1) Community culture construction

The rich cultural life is of important significance to promote villagers' spiritual life, and the community culture is a system formed by community people's behaviors at all aspects. The community culture construction is good for meeting community people's cultural demand, promoting spiritual civilization, and enhancing community cohesion.

(2) Living habit

The living habit can reflect the condition of spiritual life. Currently, the relationship between material consumption and personal happiness is very little, and the quantity of material wealth people enjoy is not completely in direct proportion to personal happiness; on the contrary, people's spiritual living condition is closely related to living habit and social relation.

(3) Sense of security and sense of belonging

People's sense of spiritual security and sense of belonging depend on living environment and urban approval, and it is also an important indicator which reflects people's spiritual living condition.

2.2 Empirical effect

2.2.1 Effect of material living condition

(1) Housing area

Shenghua Village covers an area of more than $250 \mathrm{mu}$, but the villagers' housing area is up to $185,000 \mathrm{~m}^{3}$; the reason is that more than $90 \%$ of villagers build their houses by themselves (house building without license), and the built houses are illegal 3-storey buildings. In this transformation of "village inside city", the land of returning to construction of Shenghua Village covered more than $120 \mathrm{mu}$, and $67 \mathrm{mu}$ were used for returning to house buildings, which were legal houses approved by planning bureau and covered an area of $116,000 \mathrm{~m}^{3}$. The remaining land of $43 \mathrm{mu}$ was used as development land where the public infrastructure was built. It was stipulated in transformation scheme that the houses were built according to the standard of $100 \mathrm{~m}^{2}$ house building area per 
person from storey 1-3 (including storey 3); if the area was insufficient, the supplement would be made. Besides, if Shenghua Village was demolished within stipulated time, everyone would be awarded with $20 \%$ of area of returning to construction; in this way, the per capital living space was $120 \mathrm{~m}^{2}$, with a slight increase compared with original per capital living space.

Table 2. Change of land-lost residents' living condition

\begin{tabular}{|l|l|l|}
\hline & Before demolition & After demolition \\
\hline Total floor area $\mathrm{m}^{2}$ & $18.5 \times 10^{4}$ & $11.65 \times 10^{4}$ \\
\hline Legal floor area $\mathrm{m}^{2}$ & 0 & $11.65 \times 10^{4}$ \\
\hline Per capita legal area $\mathrm{m}^{2}$ & 0 & 120 \\
\hline
\end{tabular}

(2) Income level

Due to low overall quality of villagers of Shenghua Village, there was no land for villagers' farming prior to transformation, and the income mainly came from rental housing and part-time work. Meanwhile, the peasants had no fear of attacks from behind, for the adverse part-time would not affect their basic life. After transformation of village inside city, the peasants lost their land and future life would change from part-time to non-agriculture, which made villagers worry about their future living condition. The problem that the villagers of Shenghua Village were commonly worried about was that they had insufficient preparations for change of lifestyle both in psychology and in technology; meanwhile, due to villagers' low cultural quality and no professional skills, the villagers could only engage in low-grade occupation while selecting the profession, and it was hard for them to have a superior feeling of income level before transformation.

From perspective of long-term development, the villagers would not fear no legality of house and reduction of living quality, and would still have superior feeling before transformation.

Table 3. Structure of villagers' income source and satisfaction degree before transformation

\begin{tabular}{|c|c|c|c|c|}
\hline $\begin{array}{l}\text { Form of income } \\
\text { source }\end{array}$ & $\begin{array}{l}\text { House for } \\
\text { rent }\end{array}$ & $\begin{array}{l}\text { Individual } \\
\text { operation }\end{array}$ & $\begin{array}{l}\text { Income form } \\
\text { wages }\end{array}$ & Others \\
\hline $\begin{array}{rr}\text { Number } & \text { of } \\
\text { households } & \\
\end{array}$ & 219 & 48 & 25 & 0 \\
\hline Proportion & $75.0 \%$ & $16.4 \%$ & $8.6 \%$ & 0 \\
\hline $\begin{array}{c}\text { Degree of income } \\
\text { satisfaction }\end{array}$ & $90.9 \%$ & $85.4 \%$ & $88 \%$ & 0 \\
\hline
\end{tabular}

(3) Employment post

The villagers of Shenghua Village commonly lacked of advantage and quality in urban employment market; besides, their basic life was guaranteed, thus the villagers were picky to the work they engaged in. The survey result shown that the unemployed labor population of the appropriate age accounted for $30 \%$, people in charge of rental housing were mainly women, and the population with stable work accounted for $25 \%$; other professions were mainly temporary worker of factory, catering industry personnel, public security personnel, supermarket waiter, business hall staff, driver, peddler, construction worker, community cleaner, private entrepreneur, and individual household, etc.; most of villagers engaged in the profession of vacancy property in urban economy. However, in compensation and settlement scheme, Shenghua Village Neighborhood Committee didn't mentioned to provide sufficient employment posts for villagers. This is a blind spot which we shall pay sufficient attention and we need to deeply ponder about.

(4) Welfare and guarantee

In 2003, Shenghua Village changed from collective system to stockholding system; such scheme was passed in 2005, and Shenghua Industry Co., Ltd. was established; all villagers became shareholders, and Shenghua Village Neighborhood Committee spared no efforts to economic development. In following share dividend at the end of each year, the share dividend for each household was up to RMB 20,000 yuan, which was 10 times of that in the beginning of 1990s. Meanwhile, Shenghua Village Neighborhood Committee purchased health insurance and social insurance for all villagers, which solved the problem of no guarantee which existed in villagers' heart for a long time.

2.2.2 Effect of spiritual living condition 
(1) Community culture construction

According to actual situation, the cultural life of Shenghua Village was not optimistic. In terms of villagers, although they changed from peasants to residents, there was little change in their cultural life compared to the past, and their entertainment and leisure were just playing card, chatting, watching TV, listening to radio, and sleeping. As for Shenghua Village Neighborhood Committee, although its members knew that enriching villagers' cultural life was an important content to enhance spiritual civilization and build a harmonious society, they often ignored this aspect of work in specific work, but focused on economic development of "village inside city".

Table 4. Villagers' demand for public cultural infrastructure

\begin{tabular}{|c|c|c|c|c|c|c|}
\hline $\begin{array}{c}\text { Demand } \\
\text { degree }\end{array}$ & $\begin{array}{c}\text { Activity } \\
\text { center }\end{array}$ & $\begin{array}{c}\text { Small } \\
\text { square }\end{array}$ & $\begin{array}{c}\text { Comprehensi } \\
\text { ve gymnasium }\end{array}$ & $\begin{array}{c}\text { Fitness } \\
\text { center }\end{array}$ & Total & $\begin{array}{c}\text { Percent } \\
\text { age (\%) }\end{array}$ \\
\hline $\begin{array}{c}\text { Great } \\
\text { demand }\end{array}$ & 45 & 31 & 6 & 38 & 120 & 41.10 \\
\hline $\begin{array}{c}\text { General } \\
\text { demand }\end{array}$ & 27 & 42 & 16 & 13 & 98 & 33.56 \\
\hline Demand & 18 & 20 & 21 & 6 & 65 & 22.26 \\
\hline $\begin{array}{c}\text { No } \\
\text { demand }\end{array}$ & 3 & 1 & 5 & 0 & 9 & 3.08 \\
\hline
\end{tabular}

(2) Living habit

With rapid economic development and improvement of living quality, the living level of villagers of Shenghua Village was also improved. Due to urban construction, the villagers' farming land was purchased by the government, and the villagers didn't live the life of "from sun to sun", but stayed at home to spend spare time; the discussion became a popular way of recreation in the village.

(3) Sense of security and sense of belonging

The villagers of Shenghua Village have lived here for several tens of years, and all of them feel unwilling to part. They are unwilling to part with neighbors they have lived together for several tens of years and established deep friendship. The common words, lifestyle, and living habit make them like relatives, just as the old saying "a good neighbor is better than a brother far off".

\section{Conclusion and suggestions}

\subsection{Conclusion}

Through analysis on material living condition indicators of transformation of Shenghua Village, Jiang'an Development Zone, Wuhan City, it is found that the villagers' housing area increases, the income increases, and the villagers obtain social primary welfare guarantee which the urban residents enjoy after transformation. However, the villagers' employment problem is not substantively solved, and this is a problem that all sectors of society pay attention to in transformation of "village inside city" so as to find out effective measures to solve this problem and improve villagers' material living quality after transformation of "village inside city".

After transformation of Shenghua Village, the villagers have a better and better material life, and also improve the requirement for spiritual life. However, the villagers worry that the good measures which benefit the people can't be implemented; meanwhile, due to change of identity, change of living habit, and fall of sense of inner security and sense of belonging, their spiritual life can't reach expected effect.

\subsection{Suggestions}

3.2.1 To provide free vocational training and vocational introduction for villagers with transformation of "village inside city"

Through vocational training of relevant institutions, it is able to improve their quality and market competitiveness to certain degree, which can make them be able to gain a firm foothold and increase income level after they thoroughly become urban people. It is strongly suggested that the government shall make full use of current labor force market information system to carry out 
collection, analysis, and delivery of market demand, arrange training institutions to carry out targeted occupational training, and connect occupational introduction information network with subdistrict and neighborhood committee network to provide convenient and free occupational training and introduction service for residents with transformation of "village inside city" and also provide employment chance for partial middle-aged people.

3.2.2 To provide employment chance via community responsibility function

The community service is characterized by large employment space, small investment, low requirement for employee's personal quality, and providing community service by local people. The community employment posts are wide, with many employment chances and flexible way of employment. In this way, the employment chance is provided for partial disadvantaged group with single skill and old age after transformation of "village inside city". The community employment has very strong development potential, and the government shall actively adopt encouragement and support measures to promote the development of community employment.

3.2.3 To solve the worries of villagers of "village inside city"

After transformation of "village inside city", although villagers can obtain certain cash compensation, after those peasants without social survival skills use up their land compensation, if they can't realize employment, their life will be easily in deep water. In the past, the peasants could obtain a relatively stable life via rental housing; however, the transformation of "village inside city" makes villagers lose this stable guarantee; the villagers all worry that they will lose current economic source after transformation, and worry that that have no strength to compete with urban residents. Therefore, it is necessary for the government to solve the problems they will face via formulating perfect social guarantee mechanism and establishing corresponding policy system, such as life, provision for the aged, and medical care.

3.2.4 To improve spiritual culture life of villagers of "village inside city"

In a sense, due to quality, ability, and other factors, after the identity changes from peasant to citizen, the villagers slightly "fear" urban civilization while they select new way of survival, and it is even hard for them to adapt to urban life; they prefer to believing the land. The urbanization forces the villagers of "village inside city" to abandon the land, keep pace with the times, and quicken the pace of life, which intangibly brings spiritual pressure for quasi-citizens. Therefore, the government shall provide relevant favorable policy to guide peasants to become a member of this city, and let peasants after transformation of "village inside city" realize harvest both in material life and in spiritual life so as to better promote harmonious urban development.

\section{Bibliography}

[1] Meng Xianglin: Survey and Analysis on Compensation for Demolition and Resident Settlement Countermeasures in Transformation of Village inside City, Journal of Hebei University of Science and Technology (Social Sciences), 2011 (1).

[2] Jia Shenghua, Zheng Wenjuan, Tian Chuanhao: Theory and Countermeasures on Stakeholders' Governance in Transformation of Village inside City, Urban Planning Forum, 2011 (5).

[3] Xu Hao, Luo Yan: Innovative Thinking for Transformation and Planning of Village inside City take Wuhan New District as an example, Urban Planning Forum, 2009 (9).

[4] Ma Wenjie: Countermeasure Research on China's Transformation of Village inside City - take Kunming City as an example, China Real Estate, 2011 (6).

[5] Liu Hongwei: Discussion on Aesthetic Consciousness of Villagers of "Village inside City" in Spiritual and Cultural Life, Journal of Jiamusi Education Institute, 2010 (2). 